Jan Ciglenecki in Nena Bobovnik

\title{
Blue Deserts: Jerome and the Origins of Insular Monasticism in the Adriatic
}

\section{Modre puščave: Hieronim in izvori otoškega meni- štva na Jadranu}

Abstract: This article focuses on Jerome as one of the first, ideologists of the desert'. To this end, it discusses his letters, Vitae, and his personal experience in the desert of Chalcis (c. 374-377 AD). Jerome is also an important historical source for the 4th-century insular eremitism in the Adriatic: in Ep. 60 to Heliodorus, he mentioned Dalmatia as one of the three archetypal deserts, equating it with Egypt and Mesopotamia. The article analyses Jerome's extant references on anchoretic communities and ascetic monks residing in Dalmatia. A special place among them was given to Bonosus, Jerome's close friend who around 374 AD moved to an unknown Northern Dalmatian island. Jerome depicted Bonosus' ascetic life on an island as an ideal that surpasses even the established forms of eremitism in more traditional desert environments. Jerome's propaganda for insulae Dalmatiae raises the question about their possible localization, which is shortly discussed in the concluding paragraphs.

Keywords: Jerome, Bonosus, Insular eremitism, Monasticism, Asceticism, Dalmatia

Povžetek: Članek se osredotoča na Hieronima kot enega prvih ,ideologov puščave! $\checkmark$ tem oziru se obrača tako k Hieronimovim pismom in hagiografijam kakor tudi k njegovi osebni izkušnji v sirski puščavi Halkis (ok. 374-377). Hieronim je pomemben tudi kot zgodovinski vir za začetke otoškega puščavništva na Jadranu v 4. stoletju: v Ep. 60, naslovljeni na Heliodora, Hieronim omenja Dalmacijo kot eno izmed treh arhetipskih puščav in jo postavlja ob bok Egiptu in Mezopotamiji. V osrednjem delu članek analizira Hieronimova pričevanja o anahoretskih skupnostih in menihih na Jadranu. Posebno mesto med njimi zaseda Bonoz, Hieronimov bližnji prijatelj iz otroštva, ki se je okrog leta 372 preselil na neznan otok na področju severne Dalmacije. Bonozovo asketsko življenje na otoku Hieronim vzporeja z najbolj znamenitimi puščavniki tistega časa. Ob Hieronimovi propagandi za insulae Dalmatiae se zastavlja vprašanje o njihovi lokaciji, ki ga avtorja obravnavata v zadnjem delu članka.

Ključne besede: Hieronim, Bonoz, otoško puščavništvo, meništvo, asketizem, Dalmacija 


\section{Introduction}

As historical fatherlands of monasticism, one usually thinks of Egypt, Palestine, and Syria. ${ }^{1}$ In Ep. 60 to Heliodorus, however, Jerome offered a different picture: alongside Egypt and the broader regions of the Near East, he mentioned the Roman province Dalmatia as one of the promised lands for zealous hermits (Bratož $2000,110)$. Moreover, Jerome referred to Dalmatia several times in his other letters and his Vitae, hence becoming the first and only source for eremitic tradition in the late 4th-century Adriatic. Firstly, this article discusses Jerome's ,ideology of the desert' and secondly, it systematically overviews the passages in Jerome's opus that mention monasticism in the Adriatic. Finally, the concluding section addresses different speculations about the possible localization of Jerome's insulae Dalmatiae.

\section{Jerome as the ,Ideologist of the Desert}

Jerome first encountered ascetic modus vivendi during his study years in Trier (before 370 AD), where he likely came across Athanasius' famous work Vita Antonii. He described this "first conversion " (Campenhausen 1972, 131; Derhard-Lesieur 2021) to asceticism in Ep. 3, where he wrote that in Trier, he devoted himself to God for the first time (Hier., Ep. 3.5.2). ${ }^{2}$ Rufinus' account corroborates this in Apologia contra Hieronymum, where Rufinus alluded to Jerome's knowledge of Greek before his conversion (Rufin., Apol. c. Hier. 2.9). ${ }^{3}$ According to some scholars, the two protagonists in Augustine's famous account of his conversion (Aug., Conf. 8.6-12) were no other than Jerome and his closest friend Bonosus. ${ }^{4}$

The next formative stage in the development of Jerome's vision of ascetic life was the time he spent in Aquileia. ${ }^{5}$ In the second half of the 4th-century, ascetic communities in Aquileia were already flourishing (Bratož 2000, 104-110). ${ }^{6}$ Even before the arrival of Jerome and Bonosus around 370 AD, the household of the future

1 For general introduction see Chitty, Derwas. 1966. The Desert a City: An Introduction to the Study of Egyptian and Palestinian Monasticism Under the Christian Empire. Oxford: Blackwell; Steidle, Basilius, ed. 1956. Antonius Magnus eremita 356-1956. Studia ad antiquum monachismum spectantia. Rome: Orbis Catholicus, Herder; Canivet, Pierre. 1977. Le monachisme syrien selon Théodoret de Cyr. Paris: Beauchesne. Primary sources for Egypt are: Athanasius, The Life of St. Anthony (critical edition: Bartelink, Gerard J. M., ed. 1994. Vie d'Antoine - Athanase d'Alexandrie. Introduction, texte critique et traduction. SC 400. Paris: Cerf), and Paladius, Historia Lausiaca (critical edition: Bartelink, Gerard J. M., ed. 1974. La storia Lausiaca. Verona: Fondazione Lorenzo Valla). For Palestine and Syria: Theodoret of Cyrus, A History of the Monks of Syria: Price, Robert M., tr. 1985 Kalamazoo: Cistercian Publications (critical edition: Canivet, Pierre, and Alice Leroy-Molinghen, ed. 1977-1979. Histoire des moines de Syrie. SC 234, 257. Paris: Cerf.)

2 „Cum post Romana studia ad Rheni semibarbas ripas /.../ ego primus coeperim velle te colere."

3 "Ante enim quam converteretur, mecum pariter et litereas Graecas et linguam penitus ignorabat."

4 Kelly refutes the hypothesis arguing that Augustine would not describe Jerome and Bonosus as indocti (1975, 30). For further discussions see Courcelle 1950, 181; Leclerc et. al. 2007, 13; Steinhausen 1951, 134.

5 On Jerome's personal accounts on his contacts with the Aquileian circle see Bratož 2013, 18-23.

6 Spinelli $(1982,273)$ labels the group of Aquileian ascetics not exactly as a cenobitic monastic commu- 
Aquileian bishop Chromatius was organized as an informal religious community, monasterium - or this is at least how Rufinus later described it. ${ }^{7}$ In Aquileia, Jerome and Bonosus met a group of ascetics - chorus beatorum (Hier., Chron. a. 374) - that nurtured their ascetic zeal. This community lasted until 374 AD, when they were parted by a "sudden whirlwind " (subitus turbo), as Jerome put it (Hier., Ep. 3.3). ${ }^{8}$

Afterwards, Jerome set out to Syria and into the desert of Chalcis, which seemed to him "the most secure harbour for a shipwrecked man « (3.3). ${ }^{9}$ This was a significant turning point in his life, for the change of environment encouraged him to write the first eulogies of anchoritic life in the desert. These eulogies set the stage for the development of his ideal image of the desert, which he later promulgated in his writings. Jerome's exalted descriptions of eremitism have significantly influenced later monastic literature in the West and inspired many other ascetics and laypeople.

,Desert as a paradise' became a recurrent topos in Jerome's writings. A meaningful paradigm shift is found in the opening of Jerome's Vita Pauli, where the classic attributes of paradise are presented as the utmost agony, while the real desert with all its hardships is described as a paradise (Šubrt 2000, 125-126). The motif of the ,desert as a paradise' also occurs in Ep. 2 where Jerome is asking a certain Theodosius, leader of the ascetic community in the Syrian desert, to pray for him to become worthy of the desert and to be allowed to join that, admirable community' (admirandum consortium), since - according to Jerome - the desert was "lovelier than any city « ${ }^{10}$ and , those lonely spots' were »made into a paradise by the saints that throng them «. ${ }^{11}$

This notion of the ,desert as a paradise' is further related to Jerome's exhortations aimed at various individuals, encouraging them to retreat from society and leave behind their city life. ${ }^{12}$ In $E p .14$, Jerome observed that "a monk cannot be perfect in his own country" (14.7.2), ${ }^{13}$ while in Ep. 58, he suggested to Paulin of Nola that he should consider a solitary life if he desires to become a true monk. In

nity, but with a strong ,fervore ascetico' that is manifested in later writings of Jerome, Rufinus, and Chromatius.

7 Apol. c. Hier. 2.9. Among the ascetics in the circle were deacon lulianus, subdeacon Niceas, monk Chrysocomas, Chromatius' brother Eusebius, who was also a deacon, and upper deacon lovinus, as well as Rufinus. Chromatius, lovinus, and Eusebius later became bishops.

8 The translations of Jerome's letters are, if not stated otherwise, taken from Philip Schaff and Henry Wace, ed. 1893. Jerome: Letters and Select Works. Nicene and Post-Nicene Fathers, Second Series, Vol. 6. Buffalo, NY: Christian Literature Publishing Co. For the Latin text of Jerome's letters Hilberg's CSEL editions are used.

9 "Syria mihi velut fidissimus naufrago portus occurrit."

10 "Spectarem desertum, omni amoeniorem civitatem." (Hier., Ep. 2)

11 „Viderem desolata ab accolis loca, quasi ad quoddam paradisi instar.» (Hier., Ep. 2) The passage is explored in depth in Cain 2009, 20-21.

12 Cf. "They [i.e. the cities] were considered as environments where all wordly wishes (power, money, sex and greed for food) prevailed, distracting people from the interest for afterlife and betraying Christ's true teaching." (Marazzi 2015, 605)

13 „Monachum in patria sua perfectum esse non posse.« Cf. Lc 4,24. 
order to abide by the true meaning of the word monachus, therefore, one needed to live alone in the desert and leave behind "cities which are the homes not of the solitaries but crowds" (58.5.1). ${ }^{14}$ In Ep. 125, he exclaimed along the same line that "a town is a prison and solitude a paradise " (125.8.1). ${ }^{15}$ In Ep. 14, one finds Jerome's famous eulogy to the desert: „O wilderness, bright with Christ's spring flowers! O, solitude, whence come those stones wherewith in the Apocalypse the city of the mighty king is built! O desert, rejoicing in God's familiar presence! « (14). ${ }^{16}$ Jerome's praise of the desert thus coincides impeccably with the concept of solitude, recently established by the first Christian ascetics as the principal criteria for ascetic life (Bobovnik and Derhard 2020).

In addition to his Epistulae, the formation of Jerome's ,ideology of the desert' can be observed in his Vitae of the legendary Desert fathers - Vita Pauli, Vita Malchi, Vita Hilarionis -, texts that mark the very beginning of Latin hagiography (Leclerc et al. 2007, 20). The first and most influential among these works is Vita Pauli, written sometime between 376 AD and 381 AD. ${ }^{17}$ The text depicts the life of St. Paul of Thebes, who is presented as preceding St. Anthony and surpassing him in his virtue. With this twist, Jerome re-writes the very origins of the Egyptian eremitic tradition as set out in the Athanasius' Vita Antonii and establishes St. Paul as the ,first hermit' (Hier., V. Paul. 1). ${ }^{18}$ In Jerome's version of the story, St. Anthony's older friend Paul is compared to Biblical figures such as the Prophets Elias, John the Baptist, and apostle Paul (13). ${ }^{19}$ In stark contrast to St. Anthony, who in Athanasius' words " could not endure learning letters " (Hier., V. Ant. 1), ${ }^{20}$ St. Paul was, according to Jerome, an educated Christian (Hier., V. Paul. 4). ${ }^{21}$ In this way, Jerome intentionally positioned erudition as an integral part of monastic life, a notion that later exerted a significant influence on monasticism in the West (Hale-Williams 2006, 39).

The three Vitae by Jerome helped to consolidate Egypt, Syria, and Palestine as the fatherlands of the $4^{\text {th }}$-century monasticism: Paul of Thebes was presented as the first hermit in the Egyptian desert, the story of Malchus took place in the Syrian desert, ${ }^{22}$ and Hilarion was an itinerant monk from Gaza. As far as the ,coverage' of main geographical regions of early monasticism in Jerome's Vitae is con-

\footnotetext{
14 "Non sunt solorum habitacula, sed multorum."

15 »Mihi oppidum carcer est et solitudo paradisus."

16 Translation by F. A. Wright. „O desertum Christi floribus vernans! O solitudo, in qua illi nascuntur lapides, de quibus in Apocalypsi ciuitas magni regis extruitur. O heremus familiari Deo gaudens!«

17 For the attempts to determinate the date see Kelly 1975, 60-61; Rousseau 2010, 133.

18 „Paulum quemdam Thebaeum principem rei istius fuisse."

19 „Vidi Eliam, uidi loannem in deserto, et uere in paradiso Paulum uidi.«

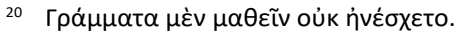

21 "Litteris tam Graecis quam Aegyptiacis adprime eruditus."

22 The story of Vita Malchi revolves around the early Christian phenomenon of ,spiritual marriage', a favourite topic for Jerome as well, who highly praised the life of ascetic virgins (subintroductae), encouraging them for the , unconsummated' marriage. For the general discussion on marital practices in Late Antiquity see Saje 2019, 989-1000, and Saje 2018, 813-823.
} 
cerned, it is interesting to note that an important episode of Vita Hilarionis occurs in (southern) Dalmatia. ${ }^{23}$ Jerome placed the Adriatic region on the map of ideal monastic landscapes, an act which he confirms by adding the Dalmatian islands to his list of promised monastic lands in Hier., Ep. 60.

\section{Insular Eremitism in the Adriatic}

Since there were no natural desert environments in the Latin West, monks who followed in the footsteps of famous Eastern ascetics looked for extreme solitude, remoteness, and wilderness that were characteristic of the deserts in Egypt and the Middle East (Marazzi 2015, 605-615; Lebecq 2013, 11). One obvious candidate for such an environment were desolate islands, isolated from the rest of the world by sea. ${ }^{24}$ These insular ,cells', well-defined by their shores, ${ }^{25}$ soon became a symbol of retreat and asceticism (Gioanni 2013, 100). The same holds true for the 4th-century anchoritic communities in the broader Adriatic region. Due to the lack of archaeological evidence from this earliest period, all knowledge about insular monasticism in the Adriatic comes from Jerome (Bratož 2000, 103-126). ${ }^{26}$ It is to this textual evidence that we now turn.

\subsection{Hier., Ep. 60}

Jerome's Ep. 60, written in 396 AD, is a consolatoria (Cain 2006, 504) composed for his friend Heliodorus, whose nephew Nepotianus died not long ago. Nepotianus had, like his uncle, abandoned civil or military service (Hier., Ep. 60.9.2) and became a presbyter in Altinum, a town in the province of Venetia-Histria, where Heliodorus was bishop. ${ }^{27}$ In Ep. 60, Jerome tried to soothe his friend's grief by praising Nepotianus' traits and impeccable ascetic values. Nepotianus, Jerome wrote, would have eagerly left everything behind when he became a monk if the love for his uncle would not have prevented him. That is why he contemplated leaving for Egypt or Mesopotamia. In this respect, he also considered Dalmatian islands:

"He [sc. Nepotianus] longed daily to make his way to the monasteries of Egypt, or to visit the communities of Mesopotamia, or at least to live a

23 See below.

24 The term, isolation' is etymologically derived from it. isola, which in turn comes from lat. insula, ,island'. The problem of water shortage could have been partly solved with the use of cisterns, which was a common practice at the time, while the abundance of seafood provided better natural resources than the harsh desert environments in the deserts of Egypt, Palestine and Syria.

25 Cf. Jerome's description of the island as a jail: "Abruptae rupes, quasi quemdam horroris carcerem claudunt." (Ep. 3.4.4)

26 For the recent archaeological survey in the North Adriatic region see Čaušević-Bully and Bully 2013; 2015. Archaeological evidence for early insular monasticism is scarce in other Mediterranean regions (e.g. Tyrrhenian Sea, Ligurian Sea) as well (Belcari 2013, 80).

27 Nepotianus was also the addressee of Ep. 52, in which Jerome offers guidance for those struggling to combine their ascetic life and ecclesiastical career. 
lonely life in the Dalmatian islands, separated from the mainland only by the strait of Altinum. But he had not the heart to forsake his episcopal uncle in whom he beheld a pattern of many virtues and from whom he could take lessons without going abroad.« $(60.10)^{28}$

\subsection{Hier., Ep. 105}

The second testimony that hints at eremitism in the Adriatic is Jerome's Ep. 105, written around 398 AD. It addresses the lost letter that was sent to Jerome by St. Augustine. The relevant passage is the following:

"You are sending me letter upon letter, and often urging me to answer a certain letter of yours, a copy of which, without your signature, had reached me through our brother Sysinnius, deacon, as I have already written, which letter you tell me that you entrusted first to our brother Profuturus, and afterwards to someone else; but that Profuturus was prevented from finishing his intended journey, and having been ordained a bishop, was removed by sudden death; and the second messenger, whose name you do not give, was afraid of the perils of the sea, and gave up the voyage which he had intended. These things being so, I am at a loss to express my surprise that the same letter is reported to be in possession of most of the Christians in Rome and throughout Italy and has come to everyone but myself, to whom alone it was ostensibly sent. I wonder at this all the more because the brother Sysinnius aforesaid tells me that he found it among the rest of your published works, not in Africa, not in your possession, but on an island of the Adriatic some five years ago." (105.1) ${ }^{29}$

The passage implies an established (monastic?) community on an unnamed insula Hadriae; however, there are no geographical clues that would allow for locating this island (Bratož 2000, 111).

\subsection{Hier., Ep. 118}

The third reference to eremitic communities in the Adriatic is found in Jerome's Ep. 118, dated 407 AD. In this letter, Jerome writes to a certain Julian, his compatriot or perhaps a neighbour (Suić 1986, 236), praising his benefactory deeds:

28 „Cumque arderet cotidie aut ad Aegypti monasteria pergere aut Mesopotamiae invisere choros vel certe insularum Dalmatiae, quae Altino tantum freto distant, solitudines occupare, avunculum pontificem deserere non audebat tota in illo cernens exempla virtutum domique habens, unde disceret."

29 „Crebras ad me epistolas dirigis, et saepe compelis, ut respondeam cuidam epistolae tuae, cuius ad me, ut ante iam scripsi, per fratrem Sisinnium diaconum exemplaria pervenerunt absque subscriptione tua et quam primum per fratrem Profuturum, secundo per quendam alium te misisse significas, et interim Profuturum retractum de itinere et Episcopum constitutum veloci morte subtractum, illum cuius nomen retices, maris timuisse discrimina et navigationis mutasse consilium. Quae cum ita sint, satis mirari nequeo, quomodo ipsa epistola et Romae et in Italia haberi a plerisque dicatur et ad me solum non pervenerint, cui soli missa est, praesertim cum idem frater Sisinnius inter caeteros tractatus tuos dixerit eam se non in Africa, non apud te, sed in insula Hadriae, ante hoc ferme quinquennium reperisse." 
"I would not, therefore, have you offer to the Lord only what a thief may steal from you or an enemy fall upon, or a proscription confiscate, what is liable to fluctuations in value now going up and now down, what belongs to a succession of masters who follow each other as fast as in the sea wave follows wave, and - to say everything in a word - what, whether you like it or not, you must leave behind you when you die. Rather offer to God that which no enemy can carry off, and no tyrant take from you, which will go down with you into the grave, nay on to the kingdom of heaven and the enchantments of paradise. You already build monasteries and support in the various islands of Dalmatia a large number of holy men. But you would do better still if you were to live among these holy men as a holy man yourself.« (118.5) $)^{30}$

The plural term monasteria and phrase multus numerus sanctorum suggest that several separate ascetic communities in the Adriatic already existed around 400 AD (Čaušević-Bully and Bully 2015, 79). However, Jerome's use of the term monasteria does not necessarily denote a coenobitic monastery but rather refers to a semi-anchoretic colony (laura) or a solitary hermitage (Bratož 2000, 110). Apart from the general mention of Dalmatia, no geographical details can be derived from this passage.

\subsection{Hier., Apologia contra Rufinum}

Further to the Epistulae, monastic communities on the Adriatic islands were mentioned twice in Jerome's Apologia contra Rufinum:

"Whence then, I beg you to consider, did the report of you [sc. Rufinus] having written these books reach me? Who was it that sowed them broadcast through Rome and Italy and the islands of the coast of Dalmatia? How did these charges against me ever come to my ears if they were only lurking in your desk and those of your friends?« (3.3.12-16) ${ }^{31}$

Jerome again mentioned Dalmatia in a later passage:

"After I repelled your charges, that is your praises, and without showing an ill will to you personally, answered the accusations, not the accuser, and inveighed against the heretics, to show that, though defamed by you, I was a Catholic; you grew angry, and raved and composed the most magnificent works against me; and when you had given them to all men to read and re-

30 „Nolo tantum ea offeras domino, quae potest fur rapere, invadere inuadere, proscriptio tollere, quae et accedere possunt et recedere et instar undarum ac fluctuum a succedentibus sibi dominis occupantur atque - ut uno cuncta sermone comprehendam - quae - velis nolis - in morte dimissurus es; illud offer, quod nullus tibi hostis possit auferre, nulla eripere tyrannis, quod tecum pergat ad inferos, immo ad regna caelorum et ad paradisi delicias. Exstruis monasteria, et multus a te per insulas Dalmatiae sanctorum numerus sustentatur; sed melius faceres, si et ipse sanctus inter sanctos viveres."

31 „Et unde, oro te, librorum tuorum ad me fama pervenit? Quis eos Romae, quis in Italia, quis per Dalmatiae insulas disseminavit? Si in scriniis tuis et amicorum tuorum latebant, ad me quomodo mea crimina pervenerunt?« 
peat, letters came to me from Italy, and Rome and Dalmatia, showing each more clearly than the last, what all the encomiums were worth with which in your former laudation you had decorated me.« (3.7. 32-40) ${ }^{32}$

In these two passages Jerome reported that Christian communities in the Adriatic were aware of concurrent affairs, particularly about an ardent polemic he had with Rufinus (Bratož 2000, 111). Jerome's former friend was now sending malicious letters across the ,Dalmatian islands' (per Dalmatiae insulas) in order to discredit him among his compatriots (Bratož 2013,9). Like with the letters, it is impossible to locate these islands on the grounds of the text alone.

\section{Eremitae Dalmaticae: Hilarion, Bonosus, Castricianus}

\subsection{Hilarion}

In Vita Hilarionis, the eponymous saint was presented as a forefather of the ascetic movement in the broader Adriatic region. According to Jerome, Hilarion travelled extensively in his late years in order to escape the crowds of admirers that appeared at his every place of residence. The same applied to Sicily, his last stop before setting sail for Dalmatia. In this context, Jerome wrote that Hilarion

"wanted to go to certain barbarous races where his name and fame were unknown. He [sc. Hesychius] therefore brought him to Epidaurus, a town in Dalmatia, where he stayed for a few days in the country near but could not be hidden." $(28.1-2)^{33}$

Ironically, Dalmatia, the country of ,barbarous races', was Jerome's fatherland. ${ }^{34}$ With , barbarous races' he might have alluded to the pagan population of this region, which was only partly Christianised in the mid-4th-century.

According to Jerome, Hilarion arrived to Epidaurus (present-day Cavtat near Dubrovnik) around 366 AD and performed two miracles. First, he saved the local population from a gigantic savage snake (28), and second, he tranquillized the sea after a devastating earthquake (29). These miracles were so remarkable that "Epidaurus and all the region roundabout tell the story to this day, and mothers teach their children to hand down the remembrance of it to posterity« (29.4). ${ }^{35}$

32 »Postquam repuli crimina, id est laudes tuas, et absque invidia tui nominis respondi criminibus, non criminatori, atque, ut me catholicum a te infamatus probarem, invectus sum in haereticos, irasceris, furis, et loculentissimos libros contra me cudis. Quos cum legendos et cantandos omnibus tradidisses, certatim ad me de Italia et urbe Roma atque Dalmatia scripta venerunt, quibus me laudatur pristinus ornasses praeconiis."

33 „Velle ad barbaras quasdam pergere nationes, ubi et nomen et sermo suus incognitus foret. Duxit itaque illum ad Epidaurum, Dalmatiae oppidum, ubi paucis diebus in vicino agello mansitans non potuit abscondi."

34 For a discussion of Jerome's Dalmatian origins, see Bratož 2013, 8-15.

35 »Hoc Epidaurus et omnis illa regio usque hodie praedicat, matresque docent liberos suos ad memoriam in posteros transmittendam. " This anecdote is mentioned also by Sozomenus in HE V.10.2-3 (Cedilnik 2004, 291-292). 
Jerome further added that his fame spread as far as Salona (29.7), ${ }^{36}$ leaving Hilarion no other choice but to escape the crowds. Thus, he sailed away usecretly by night in a small boat« (29.7). ${ }^{37}$

Another passage in Vita Hilarionis should be considered in the context of the previously discussed ,ideology of the desert' and its insular forms. ${ }^{38}$ Hilarion was beset by familiar problems with admirers already in Egypt long before he visited Dalmatia. To this end, he contemplated on how to avoid them:

"Having then left Bruchium, he entered the oasis through the trackless desert and there abode for a year, more or less. But, inasmuch as his fame had travelled thither also, he felt that he could not be hidden in the East, where he was known to many by the report and by sight, and began to think of taking ship for some solitary island, so that having been exposed to public view by the land, he might at least find concealment in the sea.« $(23.7)^{39}$

Described here is an ideal of the insular ascetic life that Hilarion himself never wholly fulfilled. While he lived in Sicily and Cyprus, these two islands did not correspond to his idea of a small and solitary island (sola insula), primarily due to their size and population density. The ideal of insular eremitism, envisaged by Hilarion, was yet to be fulfilled by later generations of ascetic monks in Dalmatia.

\subsection{Bonosus}

According to Jerome, the most remarkable insular hermit was his close friend Bonosus. Jerome considered him as an inseparable brother, writing in Ep. 3 that they were " fostered in the bosoms of the same nurses, and carried in the arms of the same bearers « (3.5). ${ }^{40}$ Afterwards, they were schoolmates in Rome, lived together in Trier (3.5.2), where they became interested in asceticism and later moved to Aquileia (Ep. 3; 7; Apol. c. Ruf. 1.4; Chron. a. 374). After the quarrel in Jerome's Aquileian ascetic circle in 374, Bonosus decided to pursue eremitic life and moved to an unknown island. Although never explicitly stated by Jerome, we can arguably assume that Bonosus settled down on one of the islands in the Adriatic, on the shores of which the city of Aquileia stood (Bratož 2000, 110).

Jerome described him as a "new inhabitant of paradise" (novus paradisi colonus) (Hier., Ep. 3.4.2), living »in the safe shelter of his island « like John (of Patmos) (7.3). ${ }^{41}$ Bonosus' island is depicted in a highly poetic manner:

\footnotetext{
36 "Mirabatur omnis civitas et magnitudo signi Salonis quoque percrebuerat."

37 »In brevi lembo clam nocte."

38 For Jerome's contribution to Late Antique conception of insular eremitism cf. Marazzi 2015, 606.

39 »Egressus ergo de Bruchio per inviam solitudinem intravit Oasim, ibique anno plus minus exacto, quia illuc qouque sua fama peruenerat, quasi iam in Oriente latere non posset, ubi multi illum et opinion et vultu noverant, ad solas navigare insulas cogitabat, ut quem terra vulgaverat, saltem maria celarent."

40 "Idem nos nutricum sinus, idem amplexus foverint baiulorum."

41 »/n tuto insulae /.../ ad exemplum loannis."
} 
"For here you have a youth educated with us in the refining accomplishments of the world, with an abundance of wealth, and in rank inferior to none of his associates; yet he forsakes his mother, his sisters, and his dearly loved brother and settles like a new inhabitant of paradise on a dangerous island, with the sea roaring round its reefs; while its rough crags, bare rocks, and desolate aspect make it more terrible still." (3.4.2) ${ }^{42}$

And in the following passage:

"Around the entire island roars the frenzied sea, while the beetling crags along its winding shores resound as the billows beat against them. No grass makes the ground green; there are no shady copses and no fertile fields. Precipitous cliffs surround his dreadful abode as if it were a prison." (3.4.4) $)^{43}$

These descriptions, which are perhaps only Jerome's inventions, again offer no firm grounds for establishing the island's location. According to Suićs theory, the above passage could refer to one of the islands in the Brioni archipelago, which lies along the Western coast of Istria (Suić 1986, 266). However, Jerome's explicit depiction of Bonosus' island as a solitary place in Ep. 3.4.2 is an argument against the theory because Brioni islands lie in close proximity to the densely populated Western coast of Istria. ${ }^{44}$ Thus, it would be more plausible to place Bonosus's island farther South or/and East of Istria among the insulae Dalmatiae.

As far as Bonosus is concerned, retreating from Aquileia to an unknown island, he became the second known Western insular hermit after St. Martin of Tours (Bratož 2000, 110), who settled on the island of Gallinaria along the Ligurian coast some 15 years before (Sulp. Sev., V. Mart. 6.5). ${ }^{45}$ However, the conditions in which Bonosus lived seem to have been more austere than those of St. Martin. The latter's insular episode lasted only a couple of years (c. 358-360 AD) that he spent accompanied by a presbyter. On the other hand, Bonosus seems to have remained a solitary insular hermit his entire life (Bratož 2000, 110, n. 53) ${ }^{46}$

Jerome painted Bonosus' saintly life as an unattainable exemplum. This can be observed in the following passage, full of biblical allusions and symbolism:

42 „Ecce puer honestis saeculi nobiscum artibus institutus, cui opes adfatim, dignitas adprime inter aequales, contempta matre, sororibus et carissimo sibi germano insulam pelago circumsonante navifragam, cui asperae cautes et nuda saxa et solitudo terrori est, quasi quidam novus paradisi colonus insedit."

43 „Totam circa insulam fremit insanum mare et sinuosis montibus inlisum scopulis aequor reclamat; nullo terra gramine viret; nullis uernans campus densatur umbraculis; abruptae rupes quasi quemdam horroris carcerem claudunt." Cf. discussion on Brioni below in "Conclusion“.

45 "Cedendum itaque tempori arbitratus ad insulam, cui Gallinaria nomen est, secessit comite quodam presbytero, magnarum virtutum viro. Hic aliquamdiu radicibus vixit herbarum: quo tempore helleborum, venenatum, ut ferunt, gramen, in cibum sumpsit. " Critical edition: Halm, Karl, ed. 1866. Sulpicius Severus, Opera. CSEL 1.

46 Jerome mentions that even Bonosus' closest friend was not with him on the island: "Nullus ibi agricolarum, nullus monachorum ne parvulus quidem quem nosti, Onesimus, quo velut fratre minusculo fruebatur, in tanta vastitate adhaeret lateri comes. « (Ep. 3.4.2) Cf. Bratož 2000, 110; Gioanni 2013, 101. 
"You tell me that Bonosus, like a true son of the Fish, has taken to the water. As for me, who am still foul with my old stains, like the basilisk and the scorpion, I haunt the dry places. Bonosus has his heel already on the serpent's head, while I am still as food to the same serpent which by divine appointment devours the earth. He can scale already that ladder of which the psalms of degrees are a type; while I, still weeping on its first step, hardly know whether I shall ever be able to say: I will lift up my eyes unto the hills, from whence comes my help. Amid the threatening billows of the world, he is sitting in the safe shelter of his island, that is, of the church's pale, and it may be that even now, like John, he is being called to eat God's book; while I, still lying in the sepulchre of my sins and bound with the chains of my iniquities, wait for the Lord's command in the Gospel: ১Jerome, come forth. B But Bonosus has done more than this. Like the prophet Jeremiah, he has carried his girdle across the Euphrates (for all the devil's strength is in the loins) and has hidden it there in a hole of the rock. " (Hier., Ep. 7.3) ${ }^{47}$

Not only was Bonosus described as "a new inhabitant of paradise«, but Jerome also went even further, likening him to Jacob (Hier., Ep. 3.4) ${ }^{48}$ and comparing him with Moses (3.4) ${ }^{49}$ and John (of Patmos) (7.3)..$^{50}$ He further described him as someone who surpasses even the Apostles (3.4), ${ }^{51}$ claiming that Bonosus experiences similar visions as John (of Patmos) (3.4)..$^{52}$ In a telling metaphor, he described Bonosus as "a son of the Fish « (filius, ixӨúos), who set out to the solitary island. He »has taken to the water (petere aquosa) (Ep. 7.3), while Jerome, considering himself too sinful, was still »haunting the dry places« (arentia sectari) (7.3).

The last testimony of Bonosus in Jerome's opus is a short passage from Chronicon, written around $380 \mathrm{AD}$, where Bonosus, Florentinus, and Rufinus are described as insignes monachi of the Aquileian circle (Hier., Chron. a. 377). ${ }^{53}$

47 „Bonosus, ut scribitis, quasi filius ix $\theta$ úoৎ, id est, piscis, aquosa petiit, nos pristina contagione sordentes quasi reguli et scorpiones arentia quaeque sectamur. Ille iam calcat super colubri caput, nos serpenti terram ex divina sententia comedenti adhuc cibo sumus. Ille iam potest summum graduum psalmum scandere, nobis adhuc in primo ascensu flentibus nescio an dicere aliquando contingat: sLevavi oculos meos in montes, unde veniat auxilium mihi< (Ps 120,1) Ille inter minaces saeculi fluctus in tuto insulae, hoc est, ecclesiae gremio, sedens ad exemplum lohannis librum forte iam devorat, ego in scelerum meorum sepulchro iacens et peccatorum vinculis conligatus dominicum de evangelio exspecto clamorem: ıHieronyme, veni forası. Bonosus, inquam, - quia secundum prophetam omnis diaboli virtus in lumbis est - trans Euphraten tulit lumbare suum ibi illud in foramine petrae abscondens." »Et sacramento Moysi serpentem in heremo suspendit.» »Ille inter minaces saeculi fluctus in tuto insulae, hoc est ecclesiae gremio, sedens, ad exemplum lohannis librum forte iam devorat."

51 "Videt gloriam dei, quam etiam apostoli nisi in deserto non viderant."

52 "Et fortasse ad exemplum lohannis aliquid videt, dum in insula commoratur."

53 „Florentinus, Bonosus, et Rufinus insignes monachi habentur. « To this passage alludes also Rufinus (Apol. c. Hier. 2.28.44). 


\subsection{Castricianus}

Besides Hilarion and Bonosus, Castricianus, a blind man of Pannonian origins, is the last insular hermit in the Adriatic mentioned by name. In Ep. 68, dated to 397 AD, Jerome wrote that Castricianus' journey to Bethlehem with the intention of visiting Jerome did not last long. When he reached Cissa, he was convinced by his ,brothers' to stay:

"My reverend son Heraclius the deacon has reported to me that in your eagerness to see me you came as far as Cissa, and that, though a Pannonian and consequently a land animal, you did not quail before the surges of the Adriatic and the dangers of the Aegean and Ionian seas. He tells me that you would have actually accomplished your purpose had not our brethren with affectionate care held you back. I thank you all the same and regard it as kindness shown. For in the case of friends, one must accept the will for the deed.« $(68.1)^{54}$

This passage confirms that there was a community of monks present in Cissa around $397 \mathrm{AD}$.

\section{Conclusion}

Insular eremitism in the Adriatic holds a special place in Jerome's writings. Jerome presented it as an ideal that surpasses even the established forms of monasticism in more traditional desert environments. He openly praised Bonosus' ascetic life on an island (petere aquosa) over the life of those who lived in desert places (arentia sectari) (Hier., Ep. 7.3). Considering the high status of the Adriatic islands in Jerome's ideal image of the desert, his propaganda for insulae Dalmatiae raises the question about their possible localization. While it is certainly not possible to establish their exact location based solely on the figurative descriptions in Jereme's texts, the above-discussed passages nevertheless provide some general indications.

The toponym Altinum, which according to Jerome's Ep. 60 was separated from the Dalmatian islands only by a strait (fretum) of the sea, can form the basis for cautious speculation about their location. Altinum was a Roman town in VenetiaHistria, located on the border of the West Adriatic lagoons, opposite the Torcello island..$^{55}$ In strictly geographical terms, the first impulse would be to interpret Jerome's phrase quae Altino tantum freto distant as the archipelago along the Italian coast right in front of the ancient Roman town. Nevertheless, it would be highly improbable for the educated Jerome, who must have been well acquainted

54 "Sanctus filius meus Heraclius diaconus mihi retulit, quod cupiditate nostri Cissam usque venisses et homo Pannonius, id est terrenum animal, non timueris Adriatici maris aestus et Aegei atque lonii subire discrimina et, nisi te pius fratrum retinuisset affectus, voluntatem opere complesses. Habeo itaque gratiam et in acceptum refero. In amicis enim non res quaeritur, sed voluntas."

55 For Altinum see Scarfi and Tombolani 1985. 
with the broader region from his time in Aquileia, to count the tiny islands on the Italian coast among the insulae Dalmatiae. Moreover, Altinum had a busy port in Jerome's time, which alone would have highly diminished the solitude of hermits living on the islands in its immediate vicinity.

A similar argument can be further used for dismissing the identification of Jerome's ,Dalmatian islands' with the islands on the Western coast of Istria, opposite the Italian mainland. ${ }^{56}$ For this to be true, the Latin word fretum must be read as , a stretch of the sea' (a possible alternative to its primary meaning ,strait'), ${ }^{57}$ which corresponds to approximately 100 kilometres of seawater separating the Istrian coast from Italy. However, the hypothesis about the islands on the Western coast of Istria seems again implausible, for Jerome would hardly confuse this region, which ecclesiastically and jurisdictionally belonged to Italy, with the Roman province of Dalmatia. In that period, the Western borders of Dalmatia followed the river Arsia (Raša), running through the Eastern part of Istria, while in turn, the whole Western coast was part of Italy. ${ }^{58}$ It is clear from the famous passage about Jerome's birthplace Stridon in De viris illustribus $(125)^{59}$ that he was well aware of the nearby provincial borders between Pannonia and Dalmatia. ${ }^{60}$ Considering the border between Italy and Dalmatia, we can therefore assume that Jerome, a native from the same area, would not ignore the well-known fact that important early Christian centres, such as Pola (Pula) and Parentium (Poreč), as well as the islands along the coast did not belong to Dalmatia.

A further argument speaking against the localization of Jerome's insulae Dalmatiae on the Western coast of Istria is their proximity to the economically flourishing, agriculturally well developed, and densely populated coastal region (Bratož 2014, 403, 406; Matijašić 1998, 334-366), altogether making the whole archipelago highly inadequate for the zealous solitude-seeking ascetics of Jerome's time.

If we discard the above hypotheses about the possible semi-anchoritic settlements in the Altinum archipelago and the Western Coast of Istria, Jerome's vague phrase quae Altino tantum freto distant could designate the broader Kvarner region further to the East, ${ }^{61}$ from where it was possible to reach the coast of Altinum via direct maritime routes with no intermediate stops. This same argument would also apply to the

56 These possibilities were proposed by Bratož and Suić, who have cautiously identified the ,Dalmatian islands' with the Brioni archipelago north-west of Roman city of Pula (Pola) (Bratož 2000, 112; Suić 1986, 266).

57 In Latin fretum can mean ,a strait', ,sound', ,channel' as well as (even if used more in poetry) ,the sea', as suggests Lewis-Short's Latin Dictionary with given examples: the sea (syn.: mare, oceanus, pelagus, pontus). Plur.: »fervet fretis spirantibus aequor«, Verg., Gerog. 1.327: »in freta dum fluvii current. «; Id., Aen. 1.607; cf. Ov., Met. 1.36: "pastor cum traheret per freta navibus Idaeis Helenen. «; Hor., Carm. 1.15.1: "fretis acrior Hadriae.".

58 Cf. the map of the borderlines between Dalmatia and Italy in Cedilnik 2004, front inner page.

59 „Hieronymus natus patre Eusebio, oppido Stridonis, quod a Gothis eversum Dalmatiae quondam Pannoniaque confinium fuit."

60 For discussion on ubication of Stridon see Bratož 2013, 8-15.

61 For a historical overview of archaeological excavations on Kornati islands and speculation about possible early monastic locations see: Radić Rossi, Irena, and Tomislav Fabijanić. Arheološka baština Kornata. In: Toponimija kornatskog otočja, Vladimir Skračić, ed. Zadar: Sveučilište u Zadru, 2013, 86-87. 
more isolated outer line of islands stretching from southwestern Kvarner (islands Unije, Susak, Žirje, Dugi otok etc.) towards Kornati archipelago in the South. On the other hand, it seems rather implausible that Jerome's phrase "a short strait from Altinum « (Hier., Ep. 60) would also comprise islands located further south than these regions. Apart from the legend of Hilarion that took place in Epidaurus, no other explicit indication in Jerome points to central parts of Dalmatia. ${ }^{62}$

The suggested localization of Jerome's insulae Dalmatiae in Ep. 60 in the Kvarner region can be further corroborated by the toponym Cissa (Hier., Ep. 68), mentioned in the context of Castricianus, who intended to visit Jerome in Bethlehem, but was held by brethren with loving care at Cissa. Based on Pliny the Elder's mention of the two islands with the name Cissa in his Naturalis historia, ${ }^{63}$ scholars distinguish between Cissa Pullaria (Istria) and Cissa Liburnica (island Pag). While the identification of the latter as island Pag is generally accepted, the question of localization of Cissa Pullaria has raised heated debates among scholars (Šonje 1980-1981, 105; Marušič 1990, 403; Suić 1996, 693; Bratož 2004, 554-556; Škunca $2011,333)$. As far as our present discussion is concerned, however, the main question is not the exact location of Cissa Pullaria, but foremost the question, which of the two islands of Cissa, mentioned in Pliny, the Elder - Cissa Pullaria (Istria) or Cissa Liburnica (Kvarner) - Jerome had in mind in Ep. 68.

According to Suićs theory, the island where Castricianus interrupted his journey to visit Jerome in Bethlehem is Cissa Pullaria. He derives his conclusions by identifying the island Cissa mentioned in Pliny the Elder (3.129) with the Brioni archipelago, for which he finds confirmation in Jerome's account of Castricianus (Hier., Ep. 68), who allegedly started his journey from Aquileia. Nevertheless, as there is no clue in Jerome that Castricianus indeed set sail from Aquileia, Suić's argument for the identification of Jerome's toponym Cissa with Brioni islands forms a petitio principii. An argument against Suić's theory is Jerome's description of Castricianus as homo Pannonius (Hier., Ep. 68.1), which would suggest that his point of departure was Pannonia and that for him, the shortest route towards Adriatic was not via Aquileia, but directly to Tarsatica (Rijeka), Senia (Senj) or any other port in broader Kvarner region. ${ }^{64}$ According to this itinerary, the toponym Cissa in Jerome's Ep. 68 would have necessarily referred to Cissa Liburnica (island

62 Noteworthy, however, is the argument proposed by Nikolina Uroda $(2013,114)$ who connects the name Ausonius, to whom Jerome entrusts the letter 118, with the inscription from Podstrana near Split, dated to the 5th-century AD. The inscription mentions a certain Ausonius (vir spectabilis) and is the only evidence for this name in the territory of the Roman province of Dalmatia.

63 »/.../ iuxta Histrorum agrum Cissa, Pullariae et Absyrtides, /.../ iuxta eas Electrides« (3.129) and »Insulae eius sinus cum oppidis /.../ Absortium, Arba, Gissa, Portunata« (3.152).

64 Suić seeks to diminish those drawbacks to his argument by referring to the Gothic invasion which has at the time caused an unstable situation on the roads in the Illyricum and could have prevented Castricianus from taking the more direct road to Kvarner (Suić 1996, 693, n. 17). This argument is not very convincing since the same would be true also regarding the roads leading from Pannonia to Aquileia. Suić seems to contradict his own claim that Jerome's Cissa is the Brioni islands while attempting to undermine Šonje's theory about ,basilica urbana' in Cissa in Novalja, arguing that the church might have as well been a monastic one. He sees the proof for this argument in Jerome (Suić 1996, 708), thus ironically supporting the Šonje's argument of identification of Jerome's Cissa with Cissa Liburnica on island Pag. 
Pag), from where Castricianus could embark on a ship to Salona and continue his journey overseas towards Bethlehem (Šonje 1980-1981, 106).

The final point to consider in Jerome's words quod cupiditate nostri Cissam in Ep. 68 is whether the toponym Cissa means the town (modern-day Novalja), which was a populated urban area at that time, or it more generally refers to the eponymous island Pag (Cissa). As mentioned above, Jerome's use of the term monasteria (Hier., Ep. 60; 118) in the late 4th-century refers to semi-anchoritic colonies rather than to coenobitic communities. Thus, it is more probable that the fratres, with whom Castricianus stayed in Cissa, were a semi-anchoritic community that deliberately moved away from urban centres. In this case, the ambiguous toponym Cissa in Ep. 68 would refer to the island rather than to the town. Island Pag (Cissa) can arguably be counted among the insulae Dalmatiae, mentioned in Jerome's Ep. 60 as one of the three promised monastic lands. Even if a more precise localization of other Dalmatian islands is not possible based on Jerome's texts alone, Ep. 60 and Ep. 68 at least seem to both point towards the broader Kvarner region.

\section{Abbreviations}

Apol. c. Hier. - Apologia contra Hieronymum.

Apol. c. Ruf. - Apologia contra Rufinum.

Aug., Conf. - Augustinus, Confessiones.

CCSL - Corpus Christianorum Series Latina.

Chron. - Chronicon.

CSEL - Corpus Scriptorum Ecclesiasticorum Latinorum.

Rufin. - Tyrannius Rufinus.

SC - Sources Chrétiennes.

Sulp. Sev., V. Mart. - Sulpicius Severus, Vita Martini.

V. Ant. - Vita Antonii.

V. Hilar. - Vita Hilarionis.

V. Pauli - Vita Pauli.

\section{References}

\section{Primary sources}

Bartelink, Gerard J. M., ed. 1994. Athanase d'Alexandrie: Vie d'Antoine; Introduction, texte critique et traduction. SC 400. Paris: Cerf.

Halm, Karl, ed. 1866. Sulpicius Severus: Opera. CSEL 1. Vienna: Verlag der Österreichischen Akademie der Wissenschaften.

Helm, Rudolf, ed. 1956. Eusebius Werke. Vol. 17, Die Chronik des Hieronymus: Hieronyim Chronicon. Die Griechischen Christlichen Schriftsteller der ersten drei Jahrhunderte 47. Berlin: Akademie.

Hilberg, Isidorus, ed. 1996. Hieronymus: Epistulae. CSEL 54, 55 and 56/1. Vienna: Verlag der Österreichischen Akademie der Wissenschaften.
Leclerc, Pierre, and Edgardo Martín Morales, ed. 2007. Trois vies de moines: Paul, Malchus, Hilarion. SC 508. Paris: Cerf.

Simonetti, Manlio, ed. 1961. Tyrannii Rufini Opera. CCSL 20. Turnholt: Brepols.

\section{Secondary sources}

Belcari, Ricarrdo. 2013. Monachesimo insulare tirrenico: Fonti documentarie e attestazioni materiali a Montecristo e nelle altre isole dell'arcipelago Toscano. Hortus artium medievalium 19:79-99.

Bobovnik, Nena, and Gina Derhard. 2020. Eremita alter philosophus: pojmovanje askeze $v$ poganski in krščanski filozofiji. Clotho 2, no. 1:5-31. 
Bratož, Rajko. 2000. Meništvo v rimskih provincah srednjega Podonavja in zahodnega Balkana. In: Alenka Klemenc, ur. Vita artis perennis: ob osemdesetletnici akademika Emilijana Cevca, 103-126. Ljubljana: ZRC SAZU.

---. 2013. Girolamo e i suoi rapporti con Aquileia. Trieste: Deputazione di storia patria per la Venezia Giulia.

---. 2014. Med Italijo in Ilirikom: slovenski prostor in njegovo sosedstvo v pozni antiki. Ljubljana: Znanstvena založba Filozofske fakultete; Zveza zgodovinskih društev Slovenije; Slovenska akademija znanosti in umetnosti.

Cain, Andrew. 2006. Vox clamantis in deserto: Rhetoric, Reproach, and the Forging of Ascetic Authority in Jerome's Letters from the Syrian Desert. Journal of Theological Studies 57, no. 2: 500-525.

---. 2009. The Letters of Jerome: Asceticism, Biblical Exegesis, and the Construction of Christian Authority in Late Antiquity. New York: Oxford University Press.

Campenhausen, Hans Freiherr von. 1972. Lateinische Kirchenväter. Stuttgart: W. Kohlhammer.

Cedilnik, Alenka. 2004. Ilirik med Konstantinom Velikim in Teodozijem Velikim. Ljubljana: Založba ZRC, ZRCSAZU.

Courcelle, Pierre. 1950. Recherches sur les Confessions de Saint Augustin. Paris: Éditions de Boccard.

Cresci, G., and M. Tirelli. 2007. Che cosa sappiamo (oggi) dell'antica Altino. Atti dell'Istituto Veneto di Scienze, Lettere ed Arti: Classe di Scienze morali, Lettere ed Arti 165: 543-560.

Čaušević-Bully, Morana, and Sébastien Bully. 2013. Esquisse d'un paysage monastique insulaire dans le nord de l'Adriatique: I'archipel du Kvarner (Croatie). Hortus artium medievalium 19:167-183.

-- -. 2015. Redovništvo na Kvarnerskim otocima od 5. do 11. stoljeća: nova arheološka istraživanja lokaliteta Sveti Petar kod Ilovika i Martinšćica na Punta Krizi. Croatian Archaeological Society Editions 30:77-103.

Derhard-Lesieur, Gina. 2021. Metaphors of Conversion to Asceticism in Jerome's Letters. Bogoslovni vestnik 81, no. 2:379-389

Fremantle, W.H., G. Lewis and W.G. Martley, ed. 1893. Jerome: Letters and Select Works. NY: Christian Literature Publishing Co.

Gioanni, Stéphane. 2013. Les, retraites insulaires' en Dalmatie du IV ${ }^{e}$ au XI ${ }^{e}$ siècle: Idéal ascétique, monastères et diplomatie pontificale. Hortus artium medievalium 19:100-113.

Kelly, John Norman Davidson. 1975. Jerome: His Life, Writings, and Controversies. London: Duckworth.

Marušič, Branko. 1990. Še o istrski Kisi (Cissa) in kesenskem škofu (episcopus Cessensis). Arheološki vestnik 41, št. 1:403-430.
Matijašić, Robert. 1998. Gospodarstvo antičke Istre: arheološki ostaci kao izvori za poznavanje društveno-gospodarskih odnosa u Istri u antici (I. st. pr. Kr. - III. st. posl. Kr.). Pula: Žakan Juri.

Page, T. E., E. Capps, and H. D Rouse, eds. 1954. Select Letters of St. Jerome. Translated by F.A. Wright. Loeb Classical Library 262. Cambridge, MA: Harvard University Press.

Radić Rossi, Irena, and Tomislav Fabijanić. 2013. Arheološka baština Kornata. In: Vladimir Skračić, ed. Toponimija kornatskog otočja, 67-98. Zadar: Sveučilište u Zadru.

Rousseau, Philip. 2010. Ascetics, Authority and the Church in the Age of Jerome and Cassian. Notre Dame: University of Notre Dame Press.

Saje, Andrej. 2018. Vpliv poročnih praks starih kultur na sklepanje zakona prvih kristjanov [Influence of Wedding Customs of Old Cultures on the Contracting of Marriage of First Christians]. Bogoslovni vestnik 78, no. 3:813-823.

-- - 2019. Sklepanje krščanskega zakona na Zahodu in Vzhodu od pozne antike do zgodnjega srednjega veka [Celebration of Christian Marriage in the West and East from the Late Roman to the Early Medieval Period]. Bogoslovni vestnik 79, no. 4:989-1000.

Scarfi, B. M., and M. Tombolani. 1985. Altino preromana e romana. Altino: Biblioteca comunale.

Spinelli, Giovanni. 1982. Ascetismo, monachesimo e cenobitismo ad Aquileia nel sec. IV. In: Antichità Altoadriatiche XXII. Vol. 1, Aquileia nel IV secolo, 273-300. Trieste: Edizioni Università di Trieste

Steinhausen, Josef. 1951. Hieronymus und Laktanz in Trier. Theologische Zeitschrift 20:126-54.

Suić, Mate. 1986. Hijeronim Stridonjanin - građanin Tarsatike. Jugoslavenska akademija znanosti i umjetnosti, no. 426:213-278.

---. 1996. Odabrani radovi iz stare povijesti Hrvatske: Opera selecta. Zadar: Ogranak Matice hrvatske; Arheološki muzej Zadar.

Šonje, Ante. 1980-1981. L'ubicazione della vescovile di Cessa, Vindemio. Atti del Centro di ricerche storiche di Rovigno 11:87-130.

Škunca, Stanko Josip. 2011. Enigma biskupije Cisse/ Cesse. Vjesnik Istarskog arhiva 18:333-344.

Šubrt, Jiří. 2000. Sic nudus et armatus in Christo solitudinem ingressus est... (The Motif of Desert in St. Jerome's Legends about the Hermits). Listy Filologické [Folia Philologica] 123, no. 3/4:223-36.

Uroda, Nikolina. 2013. Beginnings of Monasticism on the Central Dalmatian Islands: Problems and Perspectives. Hortus artium medievalium 19:113121.

Williams, Megan Hale. 2006. The Monk and the Book: Jerome and the Making of Christian Scholarship. Chicago; London: The University of Chicago Press. 